Arch Virol (1994) 138: 117-134

\title{
The $\mathbf{S 1}$ glycoprotein but not the $\mathrm{N}$ or $\mathrm{M}$ proteins of avian infectious bronchitis virus induces protection in vaccinated chickens
}

\author{
J. Ignjatovic and L. Galli \\ CSIRO Division of Animal Health, Animal Health Research Laboratory, \\ Park ville, Victoria, Australia
}

Accepted March 31, 1994

\begin{abstract}
Summary. The S1, N and M proteins, obtained from the nephropathogenic $\mathrm{N} 1 / 62$ strain of infectious bronchitis virus (IBV) by immunoaffinity purification with monoclonal antibodies, were used for immunization of chickens. For all three antigens multiple immunizations were necessary for induction of an antibody response. Protection of chickens vaccinated with the S1 glycoprotein against virulent challenge was demonstrated by the complete absence of virus in tracheas and kidneys of vaccinated chickens. Following four immunizations with the S1 glycoprotein $71 \%$ and $86 \%$ of chickens were protected at the level of tracheas and kidneys, respectively. Three immunizations with the S1 glycoprotein protected $70 \%$ and $10 \%$ of chickens at the level of kidney and trachea, respectively. Neither the $\mathrm{N}$ nor the $\mathrm{M}$ antigen induced protection to a virulent challenge with the nephropathogenic N1/62 strain of IBV after four immunizations. Virus neutralizing, haemagglutination inhibiting and ELISA antibodies were detected in chickens immunized with the S1 glycoprotein and inactivated N1/62 virus, however there was no correlation between the presence of any of these antibodies and protection.
\end{abstract}

\section{Introduction}

Infectious bronchitis viruses (IBVs) are members of the Coronaviridae family, enveloped viruses that contain single-stranded RNA of positive polarity. IBVs induce highly contagious respiratory infections or interstitial nephritis [19] in chickens of all ages and the disease is of considerable economic importance. The disease syndrome induced by IBVs is controlled by vaccination with live attenuated vaccines, however "vaccine breaks" due to variant strains have often been reported. Variant strains may arise fiom vaccine viruses by mutation and/or recombination $[22,35]$. The scope therefore exists for introduction of a subunit vaccine to replace live vaccination [29]. The antigen which induces protective immunity in IBV-infection has not been identified thus far. 
IBV contains four structural proteins. The S1 and S2 glycoproteins with $\mathrm{M}_{\mathrm{r}}$ of $92 \mathrm{~K}$ and $84 \mathrm{~K}$, respectively form the peplomer (S), the club-shaped oligomer that protrudes from the viral envelope. In the peplomer $S$, the $S 2$ glycoprotein forms the stalk and act as anchorage for the $S 1[5,7]$. The membrane $(\mathrm{M})$ glycoprotein, heterogeneously glycosylated with $\mathbf{M}_{\mathrm{r}}$ s ranging from $27 \mathrm{~K}$ to $36 \mathrm{~K}$ is embedded in the lipid bilayer and partially $(10 \%)$ exposed at the outer surface. The nucleocapsid $(\mathrm{N})$ protein is a basic phosphoprotein with $\mathrm{M}_{\mathrm{r}}$ of $52 \mathrm{~K}$ which is associated with viral RNA [4]. In the virion the structural proteins are present at a molar ratio of $1(\mathrm{~S}): 6(\mathrm{M}): 15(\mathrm{~N})[6]$.

The S1 glycoprotein induces virus neutralizing (VN) and haemagglutination inhibiting $(\mathrm{HI})$ antibodies $[8,9,20,27]$, enables virus entry into the cell [9] and virus spread by cell fusion $[14,30]$. The S1 glycoprotein of IBV has been considered to be the most likely inducer of protection. Inactivated IBV lacking the $\mathrm{S} 1$ glycoprotein did not induce protection in the trachea of immunized chickens whereas whole inactivated IBV protected chickens against virulent challenge [9]. However, chickens vaccinated with the purified peplomer S were not protected against virulent IBV challenge [8]. The peplomer $\mathrm{S}$ of murine hepatitis virus (MHV), another coronavirus, was shown to carry determinants for induction of protective immunity $[11,16,21]$. Mice immunized with the purified peplomer $\mathrm{S}$, containing the $\mathrm{S} 1$ and $\mathrm{S} 2$ glycoproteins, were protected from mortalities following virulent challenge. Immunization with synthetic peptides homologous to two conserved regions in the $\mathrm{S} 2$ glycoprotein of the peplomer $\mathrm{S}$ of $\mathrm{MHV}$ protected mice from virulent challenge, indicating that the protective epitopes might be located on the $\mathbf{S 2}$ glycoprotein of the peplomer $\mathrm{S}[21,32]$. The S2 glycoprotein, which anchors the S1 glycoprotein of the peplomer to the viral membrane, may in IBV, carry also epitopes for crossreactive ELISA and weak $\mathrm{VN}$ antibodies $[23,24]$. The region in the $\mathrm{S} 2$ glycoprotein inducing cross-reactive antibodies was found to be immunodominant and conserved in the majority of IBV strains and the $S 2$ glycoprotein therefore has been suggested as a suitable for development of an IBV vaccine [24]. The role of the $\mathrm{N}$ and $\mathrm{M}$ antigens in induction of protective immunity is unknown. Hasony and Macnaughton [16] have shown that neither the $N$ nor the $M$ proteins of $\mathrm{MHV}$ induce protection in immunized mice. More recent studies have indicated that the $\mathrm{N}$ protein of IBV carries T-cell epitopes and that it may have a role to play in immunity and protection $[2,3]$.

The work reported here provides evidence that multiple immunization with purified S1 glycoprotein is able to protect chickens against challenge with virulent IBV.

\section{Materials and methods}

\section{Partially purified and inactivated virus}

The nephropathogenic N1/62 ("T") strain of IBV, egg passage 7, was used. Virus titres [expressed as median ciliostatic doses $\left.\left(\mathrm{CD}_{50}\right)\right]$ and virus infectivity in tissue samples were assayed in tracheal organ cultures [12]. To obtain partially purified virus approximately $10^{4} \mathrm{CD}_{50}$ of $\mathrm{N} 1 / 62$ was inoculated into the allantoic sac of 11-day-old embryonated chicken 
eggs which were incubated for $48 \mathrm{~h}$ at $37^{\circ} \mathrm{C}$. After chilling overnight at $4{ }^{\circ} \mathrm{C}$, allantoic fluid was collected, centrifuged at $3000 \mathrm{~g}$ for $30 \mathrm{~min}$ and virus pelleted by centrifugation at $48000 \mathrm{~g}$ for $1 \mathrm{~h}$ in a Beckman ultracentrifuge using SW 28 rotor. The virus pellet was resuspended in PBS pH 7.2 (1:30 of the original volume). For inactivated virus, partially purified N1/62 was incubated with $0.05 \%$-propiolactone (Sigma Chemical Co, St Louis, MO, U.S.A.) at $37^{\circ} \mathrm{C}$ for $4 \mathrm{~h}$ and then overnight at $4^{\circ} \mathrm{C}$. Absence of infectivity was confirmed by assay in tracheal organ cultures.

\section{Preparation of immunoaffinity columns}

Monoclonal antibodies (MAbs) designated 5, 16 and 2, directed against epitopes on the S1, N and M proteins of IBV, respectively, [18] were used to construct affinity columns. The IgG was precipitated from ascitic fluid with $\left(\mathrm{NH}_{4}\right)_{2} \mathrm{SO}_{4}$ (final concentration $40 \% \mathrm{w} / \mathrm{v}$ ). After dialysis against PBS, $10 \mathrm{mg}$ of IgG was coupled to $1.5 \mathrm{~g}$ of $\mathrm{CNBr}$-Sepharose $4 \mathrm{~B}$ (Pharmacia, Uppsala, Sweden) according to the manufacturer's instructions. Unreactive groups on the gel were blocked using $200 \mathrm{mM}$ glycine $\mathrm{pH} 8.0$ and non-bound IgG was removed by three cycles of washing with $100 \mathrm{mM} \mathrm{NaHCO}_{3}$ buffer $\mathrm{pH} 8.3$ containing

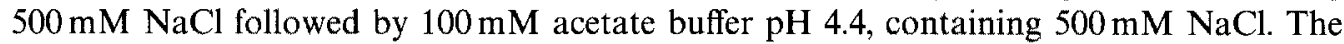
MAb-CNBr Sepharose 4B (immunoadsorbent) was stored in PBS containing $0.1 \%$ Nonidet P40 (NP40) and 0.01\% thiomersal (BDH Laboratories, Poole, England). Just before use, the immunoadsorbent was washed twice with $40 \mathrm{ml}$ of PBS and twice with $40 \mathrm{ml}$ of $2 \%$ NP40 in PBS.

\section{Purification of the $S 1, N$ and $M$ proteins by immunoaffinity chromatography}

The method described by Mockett [26], was used with some modifications. In brief: partially purified $\mathrm{N} 1 / 62$ virus (usually $10 \mathrm{ml}$ ) was mixed for $2 \mathrm{~h}$ at room temperature with $10 \mathrm{ml}$ of $4 \%(\mathrm{v} / \mathrm{v}) \mathrm{NP} 40$ in a Dounce homogenizer. After centrifugation at $17000 \mathrm{~g}$ for $15 \mathrm{~min}$, the supernatant containing soluble proteins was mixed with the MAb-immunoadsorbent overnight at $4{ }^{\circ} \mathrm{C}$ using a rotary mixer. The gel (usually $7 \mathrm{ml}$ ) was washed twice with $40 \mathrm{ml}$ of $2 \%$ NP40 in PBS and twice with $40 \mathrm{ml}$ of $0.1 \%$ NP40 in PBS. The MAb-immunoadsorbent was poured into a chromatography column (Bio-Rad Laboratories, Richmond, CA, U.S.A.) and washed with $0.1 \%$ NP40 in PBS $(40 \mathrm{ml})$ and $0.1 \%$ octylglucoside (Sigma Chemical Co, St Louis, MO, U.S.A.) in PBS ( $20 \mathrm{ml})$. Proteins were eluted using $20 \mathrm{ml}$ of $100 \mathrm{mM}$ glycine $\mathrm{pH} 2.5$ containing $0.1 \%$ octylglucoside into tubes containing $100 \mu \mathrm{l}$ of $2 \mathrm{M}$ phosphate buffer $\mathrm{pH}$ 9.2. Flow rate was $30 \mathrm{ml} / \mathrm{h}$ and fractions of $1.5 \mathrm{ml}$ were collected. A sample from each fraction (usually $25 \mu \mathrm{l}$ ) was used in direct ELISA and SDS-PAGE to determine the titre and purity of the eluted protein. Following elution, fractions were immediately dialyzed against PBS for $24 \mathrm{~h}$. Fractions with peak ELISA activity and optical density were pooled, concentrated using Centricon units (Amicon, Beverly, MA, U.S.A.) and used immediately for immunization of chickens. The amount of $\mathrm{S} 1, \mathrm{M}$ and $\mathrm{N}$ used for immunization was estimated by measuring the optical density at $280 \mathrm{~nm}$ using a U-2000 spectrophotometer (Hitachi, Japan) and by titration in direct ELISA. Detection limits for the purified S1, N and $M$ proteins in direct ELISA were 10,5 and $20 \mathrm{pg}$, respectively. The protease inhibitor phenylmethylsulfonyl fluoride (Sigma Chemical Co, MO, St Louis, MO, U.S.A.), $1 \mathrm{mg} / \mathrm{ml}$, was included in all steps during purification of the $\mathrm{N}$ protein.

\section{Direct ELISA}

Fractions collected from the MAb-immunoadsorbent and partially purified inactivated $\mathrm{N} 1 / 62$ were diluted in $500 \mathrm{mM}$ carbonate bicarbonate buffer $\mathrm{pH} 9.5$ and $100 \mu$ added to 
the wells of polystyrene microtiter plates (Disposable Products, Adelaide, Australia). After overnight incubation at $37^{\circ} \mathrm{C}$, wells were washed three times with PBS containing $0.05 \%$ Tween 20 and ascitic fluid of MAbs 2,5 and 16 (diluted 1:500) added. After incubation for $1 \mathrm{~h}$ at room temperature and washing, goat-anti mouse IgG-HRP conjugate (Bio-Rad Laboratories, Richmond, CA, U.S.A.) was added and incubated for $1 \mathrm{~h}$. After washing, the substrate solution containing $1 \mathrm{mg} / \mathrm{ml}$ of 5 -aminosalicylic acid (Merck, Darmstadt, Germany) in phosphate buffer $\mathrm{pH} 5.95$, supplemented just prior to use with $\mathrm{H}_{2} \mathrm{O}_{2}$ to give a final concentration of $0.005 \%$, was added. The absorbance at $450 \mathrm{~nm}$ was measured in a Titertek Multiskan (ICN, Costa Mesa, CA, U.S.A.) after $1 \mathrm{~h}$.

\section{ELISA for IBV antibodies}

Microtiter plates were coated with $200 \mu \mathrm{g}$ in $100 \mu \mathrm{l}$ of partially purified N1/62 virus diluted in $500 \mathrm{mM}$ carbonate bicarbonate buffer $\mathrm{pH} 9.5$, overnight at $37^{\circ} \mathrm{C}$. Plates were washed three times with PBS containing 0.05\% Tween 20. Chicken serum, diluted 1:50 and then in $\log _{2}$ dilutions was added and incubated for $1 \mathrm{~h}$ at room temperature. After washing, goat anti-chicken IgG-HRP conjugate (Kirkegaard \& Perry Labs, Gaithersburg, MD, U.S.A.) was added and incubated for $1 \mathrm{~h}$ at room temperature. Substrate solution containing 5-aminosalicylic acid and $\mathrm{H}_{2} \mathrm{O}_{2}$ was added after washing and the absorbance at $450 \mathrm{~nm}$ measured after $1 \mathrm{~h}$.

\section{$P A G E$ and immunoblotting}

SDS-PAGE was performed in a discontinuous slab gel with a $10 \%$ acrylamide concentration in the separating gel. Proteins were detected by Coomassie Brilliant Blue or silver staining (Bio-Rad Laboratories staining kit). For immunoblotting, proteins separated by SDSPAGE were transferred electrophoretically from the gel to a nitrocellulose membrane for $1 \mathrm{~h}$ at $200 \mathrm{~V}$. After transfer, the nitrocellulose sheet was incubated in $10 \mathrm{mM}$ Tris- $\mathrm{HCl}$, $150 \mathrm{mM} \mathrm{NaCl}, \mathrm{pH} 7.4$ (TBS) containing 5\% skim milk powder (blotto). The nitrocellulose sheet was either cut into strips $(0.4 \mathrm{~cm})$ or left intact and incubated with ascitic fluid of MAb, diluted 1:500 or 1:4000, or chicken sera diluted 1:20, in blotto. The nitrocellulose sheet or strips were then washed with TBS containing $0.05 \%$ Tween 20 and incubated with goat-anti mouse IgG-HRP or goat-anti chicken IgG-HRP conjugates diluted in blotto. After washing with TBS containing $0.05 \%$ Tween 20 , strips were incubated for 1 min with luminol, enchanced chemiluminescence detection kit (Amersham, Buckinghamshire, U.K.) and exposed to an X-ray film (Fuji) or 4-chloro-1-napthol (Sigma Chemical Co, St Louis, MO, U.S.A.), $1 \mathrm{ml}$ of $3 \mathrm{mg} / \mathrm{ml}$ solution in methanol to which $5 \mathrm{ml}$ of TBS containing $0.005 \%$ $\mathrm{H}_{2} \mathrm{O}_{2}$ was added.

\section{$V N$ and $H I$ assays}

$\mathrm{VN}$ test was performed in tracheal organ cultures with $100 \mathrm{CD}_{50}$ of $\mathrm{N} 1 / 62$ virus against $\log _{2}$ dilutions of chicken sera (strating dilution 1:20) [12]. HI test was performed as described previously [18].

\section{Immunization of chickens with purified $S 1, N$ and $M$ proteins}

Fourteen, day-old, specified pathogen-free white leghorn chickens were placed into positive pressure isolation units. At 2 weeks of age 10 chickens in each isolation unit were inoculated in the leg muscle with approximately $50 \mu \mathrm{g}$ of purified $\mathrm{S} 1, \mathrm{~N}$ or $\mathrm{M}$ protein, in $0.8 \mathrm{ml}$, or $200 \mu \mathrm{g}$ of inactivated N1/62 virus, in $0.8 \mathrm{ml}$; all emulsified in complete Freund's adjuvant 
(1:1). Four chickens in each isolation unit were left uninoculated to ascertain that infection with live virus did not occur in the groups for the duration of the experiment. Just before challenge these noninoculated chickens were removed from the inoculated groups and placed together in a separate isolation unit as controls. Ten chickens in one additional group, housed separately, were immunized with $10^{4} \mathrm{CD}_{50}$ of live N1/62 virus in $100 \mu 1$, intraocularly. Booster vaccinations of the purified $\mathrm{S} 1, \mathrm{M}$ and $\mathrm{N}$ proteins and inactivated N1/62 virus, in Freund's incomplete adjuvant (1:1), in the same amounts as used for the primary immunization, were given at approximately four weekly intervals. Chickens were bled just before each booster vaccination for collection of sera. Three separate experiments were performed. In the first experiment chickens were immunized twice with the purified $S 1, N$ and $M$ antigens and live and inactivated $N 1 / 62$ virus and challenged with $10^{4} C D_{50}$ of $\mathrm{N} 1 / 62$ virus, in $100 \mu$, intraocularly three weeks following the second immunization. In the second and third experiment chickens were immunized three and four times, respectively, and challenged three weeks following the last immunization. Five days after challenge, chickens were killed and trachea and kidney tissue collected. Tracheal scrapings, collected in $2 \mathrm{ml}$ of Medium 199 (Commonwealth Serum Laboratories, Melbourne, Australia) supplemented with penicillin $(100 \mathrm{IU} / \mathrm{ml})$ and streptomycin $(100 \mu \mathrm{g} / \mathrm{ml})$ and kidney homogenates $(20 \% \mathrm{w} / \mathrm{v}$ suspension in Medium 199) were assayed for the presence of infectious virus in tracheal organ cultures. In some groups there were losses during the experiments due to cannibalism. The amount of $200 \mu \mathrm{g}$ of purified N1/62 antigen used for immunization corresponds to approximately $3 \times 10^{8} \mathrm{CD}_{50}$ of infectious virus; $50 \mu \mathrm{g}$ of purified $\mathrm{S} 1, \mathrm{~N}$ and $\mathrm{M}$ proteins contained between 10 and 20 times higher titres of the respective antigen than was contained in $200 \mu \mathrm{g}$ of $\mathrm{N} 1 / 62$ as determined by direct ELISA.

\section{Antisera to synthetic peptides corresponding to a defined region in the S1 and S2 glycoproteins}

The nucleotide sequence of the gene coding for the peplomer S (S1 and S2 glycoproteins) of N1/62 strain of IBV has been determined [Sapats S, Wright PJ and Ignjatovic J, in preparation]. From the predicted amino acid sequence of the peplomer S, two peptides homologous to the amino acid residues 188 to 203 (located within the S1 glycoprotein) and 566 to 583 (located within the S2 glycoprotein) were chemically synthesized. For the peplomer S of Massachusetts 41 strain of IBV, corresponding amino acid residues are at positions 187 to 202 and 553 to $570[22,23]$ respectively. These two peptides, referred to as $\mathrm{S} 1$ and S2 peptides, respectively, had the following sequence: NH2-188-Lys-Ala-ValSer-Ala-Ala-Gly-Val-His-Phe-Lys-Ala-Gly-Gly-Pro-Isol-203-COOH and NH2-566-Asn-CysPro-Tyr-Val-Ser-Tyr-Gly-Lys-Phe-Cys-Ile-Lys-Pro-Asp-Gly-Ser-Ile-583-COOH. Synthetic peptides were conjugated to diphtheria toxoid by the glutaraldehyde procedure. At the $\mathrm{C}$-terminus of the $\mathrm{S} 1$ peptide cysteine was included to facilitate conjugation. The $\mathrm{N}$-terminus of the S2 peptide was acetylated and the peptide conjugated to diphtheria toxoid via the lysine side-chain. Peptide synthesis and conjugation was performed by Chiron Mimotopes Pty. Ltd., Clayton, Australia. The peptide: diphtheria toxoid ratio in the conjugate was 1:6.2 and 1:15 for the S1 and S2 peptides, respectively. Four-week-old, specified pathogenfree chickens were inoculated four times intramuscularly with peptide-diphtheria toxoid conjugates emulsified in complete (day 0 ) or incomplete (day 28, day 56, day 86) Freund's adjuvant. Approximately $50 \mu \mathrm{g}$ of synthetic peptide was contained in each inoculum. Chickens were bled 3 weeks following the last immunization and the specificity of anti-peptide sera, at dilution of 1:40, was determined in WB using the N1/62 strain of IBV. 


\section{Statistical analysis}

Level of protection and prevalence of seropositive chickens were compared between groups by the non-parametric Fisher's exact test using Tadpole statistical package for personal computers.

\section{Results}

\section{Purification of the $S 1, N$ and $M$ proteins}

The S1, $\mathrm{N}$ and $\mathrm{M}$ proteins were obtained from partially purified N1/62 virus by immunoaffinity chromatography using MAbs 5, 16 and 2, directed against the S1, $N$ and $M$ proteins respectively. Silver staining and WB of fractions eluted from the MAb-immunoadsorbents (Fig. 1) showed that the preparations of the $\mathrm{S} 1$ and $\mathrm{N}$ antigens were not contaminated with each other and were largely free from the other proteins found in allantoic fluid. Preparations of the $\mathrm{M}$ protein were also not contaminated with either the $\mathrm{N}$ nor the $\mathrm{S} 1$ proteins however some preparations of $M$ contained a protein with approximate $M_{r}$ of $45 \mathrm{~K}$ (Fig. 1a, lane 3). As this $45 \mathrm{~K}$ protein did not react with anti-N and anti-S1 MAbs and with anti-N1/62 chicken sera either in WB (Fig. 1b, lane 3) or direct ELISA it is likely to be a protein from allantoic fluid. Purified $\mathrm{N}$ and S1 proteins reacted with their respective MAbs in WB (Fig. 1b, lanes 1 and 4) and direct ELISA (results not shown) as well as with anti-N1/62 chick sera in both WB and direct ELISA (results not shown) in titres that did not differ markedly

(a)

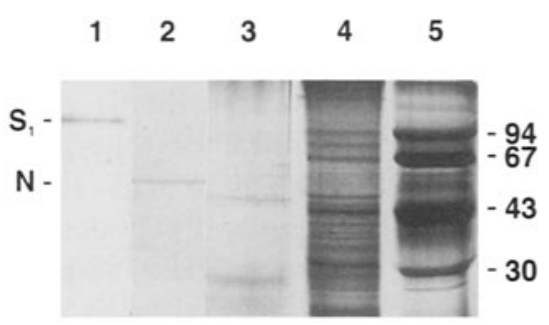

(b)

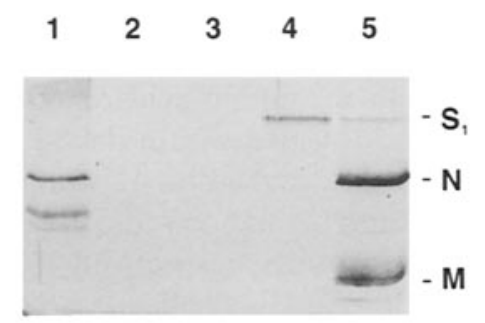

Fig. 1. Purity of the $S 1, N$ and $M$ protein preparations following recovery from the immunoaffinity column. Anti-S1, $-\mathrm{N}$ and $-\mathrm{M}$ monoclonal antibodies were each coupled to the $\mathrm{CNBr}$-Sepharose 4B. Detergent-solubilised partially purified N1/62 virus was mixed with the MAb-immunoadsorbent and bound material eluted using $100 \mathrm{mM}$ glycine $\mathrm{pH}$ 2.5. After dialysis against PBS, fractions were subjected to electrophoresis in a $10 \%$ SDS-PAGE slab gel and either $\mathbf{a}$ silver stained or $\mathbf{b}$ transferred to a nitrocellulose membrane and reacted with a mixture of monoclonal antibodies directed against the $S 1, N$ and $M$ proteins. Immune complexes were detected by incubation with anti-mouse IgG-HRP conjugate and 4-chloro-1-naphthol. a Silver-stained SDS-PAGE of the immunoaffinity purified $\mathrm{S} 1, \mathrm{~N}$, and $\mathrm{M}(1,2$ and 3 , respectively), whole $\mathrm{N} 1 / 62$ virus before applied onto the immunoadsorbent (4) and $M_{r}$ markers (5) phosphorylase $b(94 \mathrm{~K})$, bovine serum albumin $(67 \mathrm{~K})$, ovalbumin $(43 \mathrm{~K})$ and carbonic anhydrase $(30 \mathrm{~K})$. b Western blotting of the immunoaffinity purified N (1), M (3) and S1 (4) proteins, whole N1/62 virus (5) and PAGE sample buffer only (2) 
from titres obtained with the same sera on untreated N1/62 antigen. Immunoaffinity purified $M$ glycoprotein did not react with anti-M MAb in WB (Fig. 1b, lane 3), however it did react with anti-M MAb and anti-N1/62 chick sera in direct ELISA when it was used as a coating antigen (results not shown). By direct ELISA the recovered $\mathrm{S} 1, \mathrm{~N}$ and $\mathrm{M}$ proteins were not contaminated with each other (results not shown). Purification of the $\mathrm{N}$ protein had to be performed in the presence of the proteinase inhibitor phenylmethylsulfonyl fluoride otherwise the complete degradation of the $\mathrm{N}$ protein occurred. Preparations of the $\mathrm{N}$ protein recovered from the MAb 16-immunoadsorbent contained usually three protein bands with approximate $\mathrm{M}_{\mathrm{r}}$ of $52 \mathrm{~K}, 43 \mathrm{~K}$ and $40 \mathrm{~K}$, the latter two being more readily visible in WB than by silver staining (Fig. 1).

The protein eluted from the MAb 5-immunoadsorbent, the MAb which is was considered to be directed against the $\mathrm{S} 1$ glycoprotein, had only one protein band on gels with approximate $M_{r}$ of between $94 \mathrm{~K}$ and $97 \mathrm{~K}$ (Figs. 1 and 2) and this protein stained well with both silver (Fig. 1a) and Coomassie (results not shown) stains. In WB with anti-N1/62 chick sera the immunoaffinity purified $S 1$ contained only one protein band with approximate $M_{r}$ of $97 \mathrm{~K}$ (Fig. 2, lane 7). The N1/62 virus contained two bands that migrated close to each other, indicative of the presence of S1 and S2 glycoproteins. Immunoaffinity purified S1 reacted in WB only with antisera to the S1 peptide (Fig. 2, lane 3) but not with antisera to the S2 peptide (Fig. 2, lane 5). Since the S1 and S2 peptides correspond to amino acid residues 188 to 203 and 566 to 583 in the $\mathrm{S} 1$ and $\mathrm{S} 2$ coding domains of the peplomer S respectively, it was therefore presumed that the protein recovered from the MAb-5-immunoadsorbent was the S1 glycoprotein of IBV.

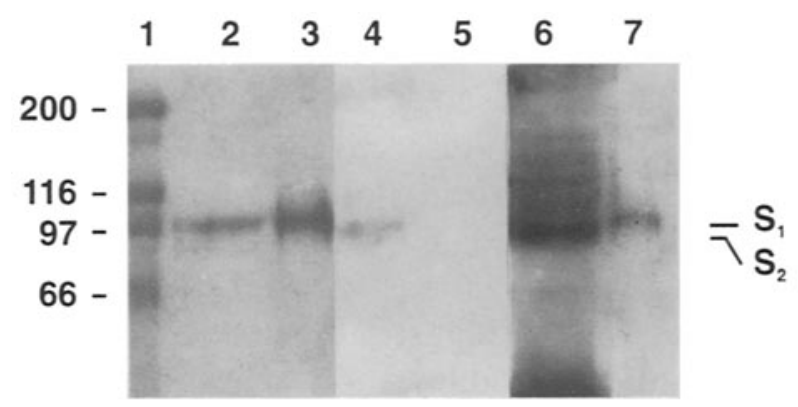

Fig. 2. Electrophoretic mobility and cross-reaction with anti-peptide sera of the $\mathrm{S} 1$ protein recovered by immunoaffinity purification. Partially purified N1/62 virus $(2,4$ and 6$)$, the protein recovered from the MAb 5-immunoadsorbent $(3,5$ and 7$)$ and biotinylated molecular weight markers (1) were subjected to electrophoresis in a $10 \%$ SDS-PAGE slab gel, transferred to a nitrocellulose membrane and reacted with chick anti-S1-peptide (2 and 3), anti-S2-peptide ( 4 and 5) and anti-N1/62 sera (6 and 7). After incubation with a mixture of anti-chick IgG-HRP conjugate and avidin, luminol was added followed by autoradiography. Biotinylated molecular weight markers were: rabbit skeletal muscle myosin $(200 \mathrm{~K})$, E. coli $\beta$-galactosidase $(116 \mathrm{~K})$, rabbit muscle phosphorylase $(97 \mathrm{~K})$ and bovine serum albumin $(66 \mathrm{~K})$ 
Ammonium isothiocyanate was used in two studies as elution buffer $[11,26]$ to recover intact peplomer $\mathrm{S}$. For that reason, $3 \mathrm{M}$ ammonium isothiocyanate in PBS, pH 7.2 was also used for elution of proteins from the MAb-immunoadsorbents, instead of glycine, while all the other conditions were the same. The $\mathrm{S} 1$ glycoprotein, and not the peplomer $\mathrm{S}$, was only recovered from the MAb 5-immunoadsorbent with ammonium isothiocyanate (results not shown). The amount and antigenicity of all three proteins, the $S 1, N$ and $M$, recovered with ammonium isothiocyanate was comparable with the amount and antigenicity of the $\mathrm{S} 1, \mathrm{~N}$ and $\mathrm{M}$ obtained with glycine as determined by their reactions with respective MAbs and polyclonal chicken sera in direct ELISA (results not shown). Elution with glycine was method of choice for this study as it allowed the repeated used of the MAb-immunoadsorbents which was not possible using ammonium isothiocyanate.

\section{Protection of chickens immunized with the purified $S 1, M$ and $N$ proteins against challenge with virulent N1/62 strain}

In there separate experiments chickens were immunized with $50 \mu \mathrm{g}$ of immunoaffinity purified $\mathrm{S} 1, \mathrm{~N}$ and $\mathrm{M}$ proteins and inactivated and live $\mathrm{N} 1 / 62$ virus at four weekly intervals. Three weeks after two, three and four immunizations chickens were challenged with live virus to assess the degree of protection afforded by the individual purified viral antigens (Table 1). Challenge virus was the nephropathogenic N1/62 strain of IBV. Since nephropathogenic IBVs replicate efficiently in both trachea and kidney, protection of both tissues was assessed by virus isolation.

As shown in Table 1, immunization with inactivated N1/62 was less effective than immunization with live $\mathrm{N} 1 / 62$. In chickens immunized twice with inactivated $\mathrm{N} 1 / 62$ virus there was some degree of protection for kidney $(33 \%)$ although this was not statistically significant $(P \geqslant 0.05)$. Three immunizations with inactivated $\mathrm{N} 1 / 62$ virus protected $80 \%$ and $60 \%$ of chickens at the level of kidneys $(\mathrm{P} \leqslant 0.001)$ and tracheas $(\mathrm{P} \leqslant 0.01)$ respectively and this level of protection did not increase with further immunizations (four immunizations, Table 1). Kidneys were consistently better protected, $80 \%$ versus $60 \%$ and $75 \%$ versus $65 \%$ following three and four immunizations with inactivated N1/62, respectively although these differences were not statistically significant $(P \geqslant 0.05)$. Vaccination with live virus totally protected kidney and trachea of all chickens $(P \leqslant 0.001)$ (Table 1).

The $\mathrm{S} 1$ glycoprotein induced protection in vaccinated chickens to a virulent challenge only after multiple immunizations (Table 1). At least three immunizations with the S1 were necessary to induce a significant level of protection $(\mathrm{P} \leqslant 0.01)$, at which time $70 \%$ of chickens were protected at the level of kidneys. At this time there was a significant difference $(P \leqslant 0.01)$ between protection induced by vaccination with $\mathrm{S} 1$ in kidney and tracheal tissues of the same birds as only $10 \%$ of chickens were protected at the level of trachea. The difference in protection between tracheal and kidney tissue was less apparent and not statistically significant $(\mathrm{P} \geqslant 0.05)$ after four immunizations with the $\mathrm{S} 1$ glycopro- 


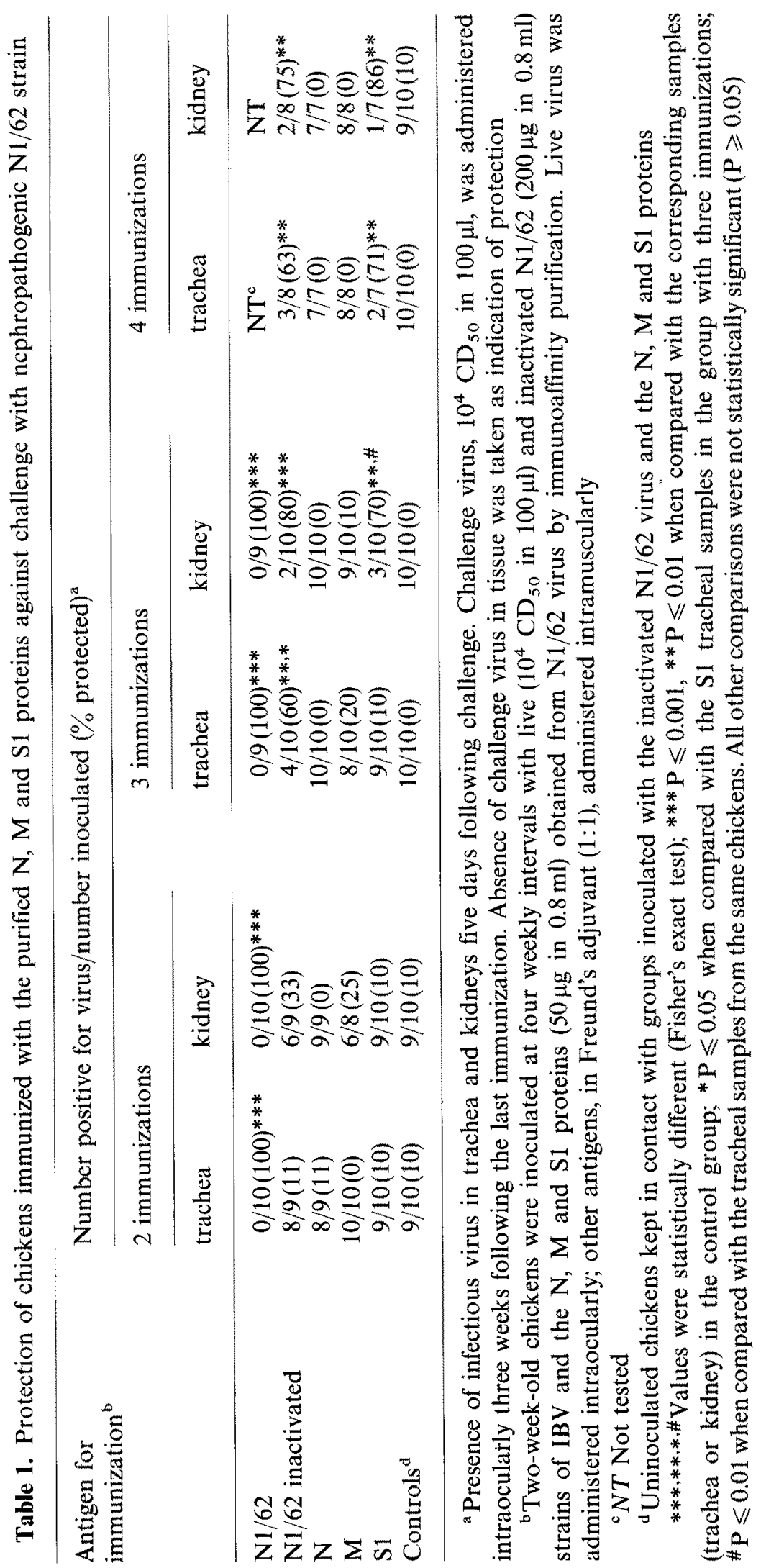


tein when $86 \%$ and $71 \%$ of chickens were protected at the level of kidney and trachea, respectively. The level of protection induced by the $\mathrm{S} 1$, after four immunizations was statistically significant $(P \leqslant 0.01)$ for both kidney and trachea.

Neither the $\mathrm{N}$ nor the $\mathrm{M}$ protein induced protection in immunized chickens (Table 1). Although the $\mathrm{N}$ protein was the most immunogenic and induced high titres of ELISA antibodies, it did not provide protection against virulent challenge and $100 \%$ of chickens had virus present in both trachea and kidneys 5 days after challenge with virulent N1/62.

\section{Antibody responses following immunization with the purified S1, $M$ and $N$ antigens}

Antibody responses following each immunization were determined by VN, ELISA, WB and HI test. Results obtained in experiment in which chickens were immunized four times with the purified $S 1, N$ and $M$ antigens and live and inactivated N1/62 virus, are shown in Table 2 and Fig.3.

Table 2. Virus neutralizing and ELISA antibodies in chickens immunized with live and inactivated $\mathrm{N} 1 / 62$ virus and the purified $\mathrm{N}, \mathrm{M}$ and $\mathrm{S} 1$ antigens obtained from N1/62

\begin{tabular}{|c|c|c|c|c|c|c|c|c|}
\hline \multirow{3}{*}{$\begin{array}{l}\text { Antigen for } \\
\text { immunization }^{b}\end{array}$} & \multicolumn{8}{|c|}{ Number positive/number tested ${ }^{a}$} \\
\hline & \multicolumn{2}{|l|}{$1^{\circ}$} & \multicolumn{2}{|l|}{$2^{\circ}$} & \multicolumn{2}{|l|}{$3^{\circ}$} & \multicolumn{2}{|l|}{$4^{\circ}$} \\
\hline & $\mathrm{VN}^{\mathrm{c}}$ & ELISA $^{c}$ & $\mathrm{VN}$ & ELISA & $\mathrm{VN}$ & ELISA & $\mathrm{VN}$ & ELISA \\
\hline $\mathrm{N} 1 / 62$ & $9 / 9$ & $9 / 9$ & $10 / 10$ & $10 / 10$ & $\mathrm{NT}^{\mathrm{d}}$ & NT & NT & NT \\
\hline $\mathrm{N} 1 / 62$ inactivated & $0 / 5$ & $0 / 5$ & $2 / 10$ & $8 / 10^{* * *}$ & $6 / 10^{* *, *}$ & $10 / 10^{* * *}$ & $8 / 8^{* * *}$ & $8 / 8 * * *$ \\
\hline $\mathrm{N}$ & $0 / 5$ & $0 / 5$ & $0 / 10$ & $10 / 10 * * *$ & $0 / 10$ & $10 / 10^{* * *}$ & $0 / 7$ & $7 / 7 * * *$ \\
\hline $\mathrm{M}$ & $0 / 5$ & $0 / 5$ & $0 / 10$ & $0 / 10$ & $0 / 10$ & $0 / 10$ & $0 / 8$ & $6 / 8^{* *}$ \\
\hline $\mathrm{S} 1$ & $0 / 5$ & $0 / 5$ & $0 / 10$ & $0 / 10$ & $1 / 10$ & $10 / 10^{* * *}$ & $5 / 7 * *$ & $7 / 7 * * *$ \\
\hline Controls $^{e}$ & $0 / 12$ & $0 / 12$ & $0 / 12$ & $0 / 12$ & $0 / 12$ & $0 / 12$ & $0 / 10$ & $0 / 10$ \\
\hline
\end{tabular}

${ }^{a}$ Antibodies measured four weeks following the first $\left(1^{\circ}\right)$, second $\left(2^{\circ}\right)$, third $\left(3^{\circ}\right)$ and fourth $\left(4^{\circ}\right)$ immunization

${ }^{\mathrm{b}}$ Two-week-old chickens were immunized at four weekly intervals with live $\left(10^{4} \mathrm{CD}_{50}\right)$ and inactivated $\mathrm{N} 1 / 62$ virus $(200 \mu \mathrm{g})$, and the $\mathrm{N}, \mathrm{M}$ and $\mathrm{S} 1$ antigens $(50 \mu \mathrm{g})$ obtained from $\mathrm{N} 1 / 62$ virus by immunoaffinity purification. Live virus given intraocularly $(100 \mu 1)$, other antigens intramuscularly in Freund's adjuvant $(1: 1,0.8 \mathrm{ml} /$ chick $)$

${ }^{\circ} \mathrm{VN}$ antibodies against $\mathrm{N} 1 / 62$ strain determined in tracheal organ cultures; for ELISA microtiter plates were coated with purified N1/62 virus and sera tested diluted 1:50

¿NT Not tested

'Uninoculated controls kept in contact with groups inoculated with inactivated $\mathrm{N} 1 / 62$ virus and the $N, M$ and $S 1$ proteins

$* * *, * * *$ Values were statistically different (Fisher's exact test); ${ }^{* * *} \mathrm{P} \leqslant 0.001,{ }^{* *} \mathrm{P} \leqslant 0.01$ when compared with the control group; $* P \leqslant 0.05$ when compared with the S1 samples positive for VN antibodies in the group with three immunizations; All other comparisons for the N, M, S1 and inactivated $N 1 / 62$ groups were not statistically significant $(P \geqslant 0.05)$ 

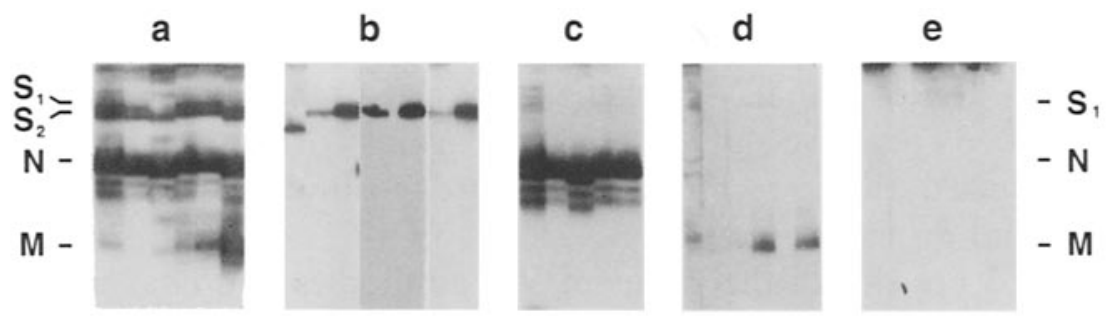

Fig. 3. Specificity of antibodies in chickens immunized four times, at four weekly intervals, with a inactivated N1/62 strain of IBV, b S1 glycoprotein, $\mathbf{c}$ N protein and d M glycoprotein obtained from N1/62 strain by immunoaffinity purification; e noninoculated controls. Purified N1/62 virus was subjected to electrophoresis in a $10 \%$ SDS-PAGE slab gel, transferred to nitrocellulose and strips incubated with representative chicken sera $(1: 20)$. After incubation with anti-chick IgG-HRP conjugate immune complexes were detected by incubation with luminol, followed by autoradiography

Two immunizations with inactivated N1/62 induced ELISA antibodies in the majority of chickens $(8 / 10)(P \leqslant 0.001)$ however only $2 / 10$ chickens $(P \geqslant 0.05)$ had $\mathrm{VN}$ antibodies (Table 2). Following three immunizations with inactivated virus, VN, ELISA and $\mathrm{HI}$ antibodies were detected in the majority of chickens $(\mathrm{P} \leqslant 0.01$ and $\mathrm{P} \leqslant 0.001$ for $\mathrm{VN}$ and ELISA antibodies respectively) (results for $\mathrm{HI}$ antibodies not shown).

Of the three purified proteins used for immunization, the $\mathrm{N}$ protein was the most immunogenic. The ELISA antibodies were detected in all chickens immunized with the $\mathrm{N}$ antigen four weeks following secondary immunization $(\mathrm{P} \leqslant 0.001)$ (Table 2). The $\mathrm{M}$ glycoprotein, given in the same amount as the $\mathrm{N}$ protein, was the least immunogenic. ELISA antibodies were detected in significant number of chickens $(P \leqslant 0.01)$ only after four immunizations. Neither the $\mathrm{N}$ nor the $\mathrm{M}$ antigens induced $\mathrm{VN}$ (Table 2) or $\mathrm{HI}$ antibodies (result not shown). The purified S1 glycoprotein induced ELISA antibodies in all chickens after three immunizations $(\mathrm{P} \leqslant 0.001)$ (Table 2 ), however only one chick had VN antibodies at that time $(\mathrm{P} \geqslant 0.05)$. Following the fourth immunization with $\mathrm{S} 1$, the majority of chickens $(5 / 7)(\mathrm{P} \leqslant 0.01)$ developed $\mathrm{VN}$ antibodies (Table 2$)$ and four of those had also HI antibodies (results not shown). The geometric mean titre of VN and HI antibodies in the group vaccinated with the S1 (1/40 and $1 / 16$, respectively) was lower in comparison to the geometric mean VN and $\mathrm{HI}$ titres in chickens vaccinated with inactivated NI/62 (1/256 and 1/64 respectively).

As shown in Fig. 3 chickens immunized four times with the purified S1, N and $M$ proteins developed only antibodies directed against the S1, N and $M$ proteins, respectively, confirming that the immunoaffinity purified antigens were free from contamination with each other. Antibodies elicited by four immunizations with inactivated $\mathrm{N} 1 / 62$ were directed to the $\mathrm{S} 1, \mathrm{~S} 2, \mathrm{~N}$ and $\mathrm{M}$ proteins (Fig. 3a). Non-inoculated chickens kept in contact with chickens inoculated with either the $S 1, N$ and $M$ proteins, or inactivated $N 1 / 62$ virus, remained antibody negative throughout the immunization experiments (Table 2, Fig. 3e). 


\section{Relationship between serum antibodies and protection}

As shown in Tables 1 and 2, chickens immunized twice with the S1 antigen were all antibody negative and not protected against virulent challenge whereas those immunized three or four times, were positive for ELISA and VN antibodies and protected.

In Table 3 are shown the status of VN antibodies and challenge virus in tracheas and kidneys of individual chickens immunized three or four times with the inactivated $\mathrm{N} 1 / 62$ virus or the $\mathrm{S} 1$ antigen. In chickens vaccinated with either the $\mathrm{S} 1$ or inactivated N1/62, there was no correlation between the presence of VN (or ELISA) antibodies and absence of virus in either trachea or kidneys. Chicks negative for VN (14/35) or HI antibodies (results for HI antibodies not shown) were also negative for challenge virus either in kidney $(10 / 35)$ or trachea $(2 / 35)$ or both $(2 / 35)$ and thus were protected. On the other hand $9 / 35$ chickens positive for $\mathrm{VN}$ and $\mathrm{HI}$ antibodies were also positive for virus either in kidney

Table 3. Status of virus neutralizing antibodies and challenge virus in chickens immunized with inactivated

$\mathrm{N} 1 / 62$ virus and the S1 glycoprotein

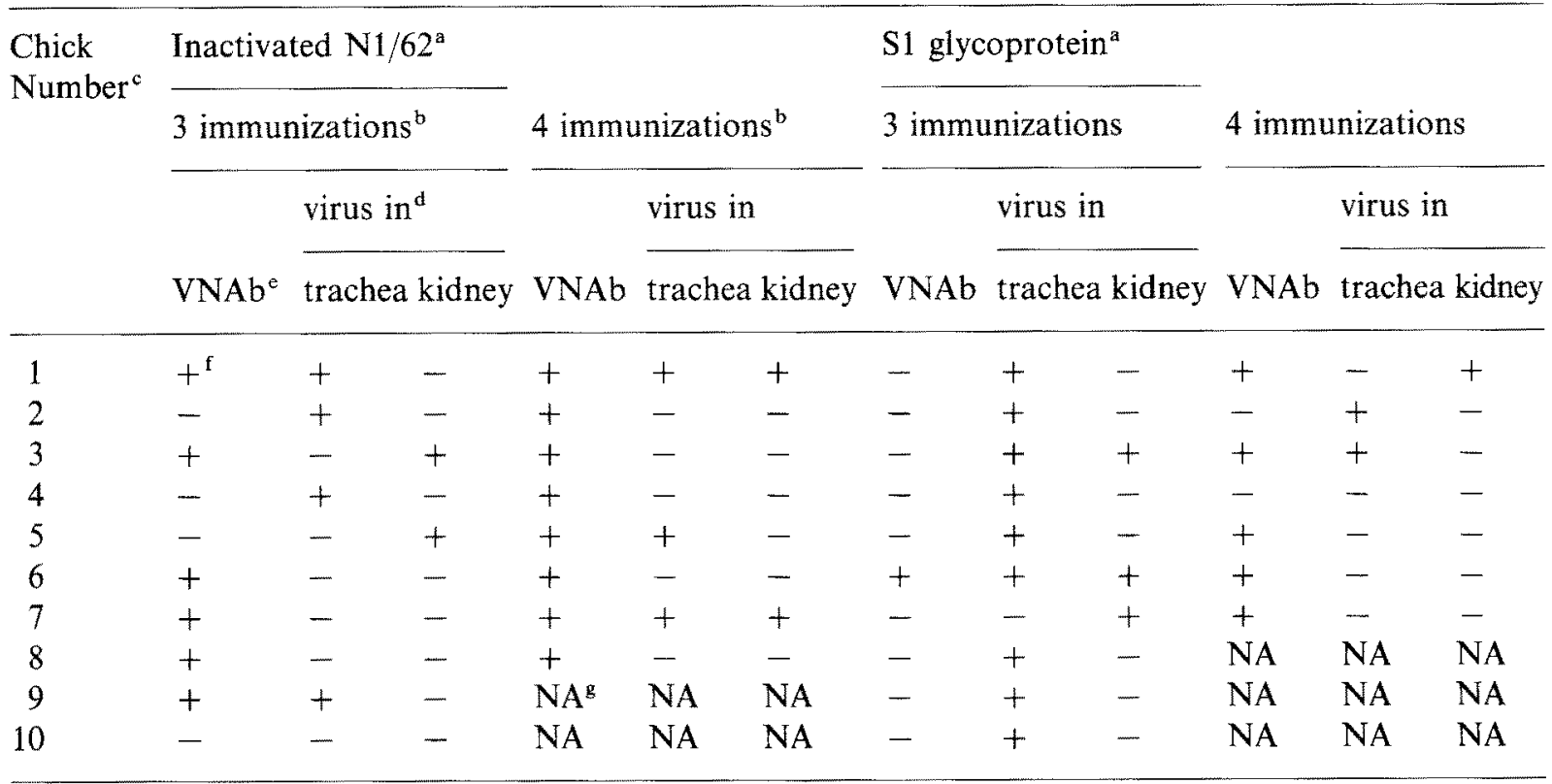

${ }^{a}$ Chickens inoculated at four weekly intervals with inactivated $\mathrm{N} 1 / 62(200 \mu \mathrm{g}$ in $0.8 \mathrm{ml})$ strain of IBV or $\mathrm{S} 1$ glycoprotein $(50 \mu \mathrm{g}$ in $0.8 \mathrm{ml})$ obtained from $\mathrm{N} 1 / 62$ by immunoaffinity purification

${ }^{b}$ Chickens were immunized three or four times, respectively and challenged three weeks after the last immunization with virulent N1/62

${ }^{c}$ Chickens were from experiments detailed in Tables 1 and 2

${ }^{\mathrm{d}}$ Challenge virus in trachea and kidney five days following challenge. Absence of challenge virus was taken as indication of protection

${ }^{8}$ VNAb Virus neutralizing antibodies against N1/62 determined in tracheal organ cultures at serum dilution of 1:20. All sera were positive for ELISA antibodies

$\mathrm{f}+,-$ Positive, negative

${ }^{\mathrm{g}} \mathrm{NA}$ Not applicable 
$(2 / 35)$ or trachea $(4 / 35)$ or both $(3 / 35)$ and were not protected. Only in $11 / 35$ chickens did the presence of VN antibodies correlated with the absence of challenge virus in trachea and kidneys. Also there was no correlation between the presence of ELISA antibodies and protection as all chickens in Table 3 were positive for ELISA antibodies.

\section{Discussion}

Our results showed that the $\mathrm{S} 1$ glycoprotein of IBV induces protective immunity against IBV-infection whereas neither the $\mathrm{N}$ protein nor the $\mathrm{M}$ glycoprotein induced any level of protection. The immunoaffinity purified protein that induced protection in this study was a single protein with $M_{r}$ of between $94 \mathrm{~K}$ and $97 \mathrm{~K}$ which induced $\mathrm{VN}$ and $\mathrm{HI}$ antibodies, properties attributed to the S1 glycoprotein of IBV $[8,27]$. The result confirmed the previous finding of Cavanagh and co-workers who have indirectly indicated that the S1 glycoprotein might be the inducer of protective immunity in IBV-infection [9]. In MHV the S2 glycoprotein has been shown to carry epitopes which induce protective immunity $[21,32]$ although the same studies did not evaluate whether the S1 glycoprotein also carries such determinants. The possible involvement of the S2 glycoprotein of IBV in protection was not evaluated in this study because of the lack of MAbs directed against this glycoprotein.

The immunoaffinity purified S1 was able to induce protection in 70 to $80 \%$ of vaccinated chickens, protection comparable to that induced by inactivated N1/62 virus having all four structural antigens. Protection induced by the purified S1 glycoprotein was complete and prevented replication of the challenge virus in trachea and kidney tissues which are the target organs for IBV replication. In studies performed with MHV protection from mortalities, but not prevention of virus replication, which still occurred, was taken as a measure of protection [11, 16, 21, 32]. In the development of an effective vaccine for control of IBV-infections in commercial poultry it is however necessary to completely prevent replication of a challenge virus in the trachea of chickens as IBV infection predisposes the trachea to invasion with opportunistic organisms such as $E$. coli resulting in debilitating respiratory disease with significant economic losses [19].

Although the $\mathrm{N}$ protein did not have a role in prevention of virus replication in trachea and kidneys it was the most immunogenic protein and induced significant titres of antibodies in all vaccinated chickens. The $\mathrm{N}$ proteins of MHV and feline infectious peritonitis virus were also shown not to be involved in protection $[16,34]$ although in one study the recombinantly expressed $\mathrm{N}$ protein of MHV protected mice against virulent challenge [36]. It has been previously suggested that the $\mathrm{N}$ protein of IBV might have a role in immunity and protection, although the direct evidence for its involvement in protection has not been provided [3].

The $M$ glycoprotein was the least immunogenic and did not induce protection in vaccinated chickens. It could not be discounted however that the 
purification procedure had adversely affected the immunogenicity of the $M$ glycoprotein. At least four immunizations with the purified $M$ glycoprotein were necessary to induce a detectable antibody response. Contrary results have been obtained thus far regarding protection induced by the $M$ glycoprotein. The M glycoprotein of MHV has been indirectly implicated in protection [15] and disease progression [25] however purified and recombinantly expressed $\mathrm{M}$ glycoprotein did not induce protection in vaccinated mice $[16,36]$. On the other hand, the recombinantly expressed $M$ glycoprotein of feline infectious peritonitis virus induced some level of protection in vaccinated kittens [34].

It is not clear to what extent the purification procedure may have affected the immunogenicity of the $\mathrm{S} 1, \mathrm{~N}$ and $\mathrm{M}$ proteins in chickens. The antigenic properties of the purified $\mathrm{S} 1$ and $\mathrm{N}$ proteins were comparable with properties of the same antigens in the purified untreated virus. Both purified proteins retained the ability to react with their respective MAbs and polyclonal sera in both native and denaturated state in a similar fashion as did the S1 and N proteins in untreated virus. Changes however were detected in the properties of the purified $\mathrm{M}$ glycoprotein as it did not react in WB with MAb although it reacted with the same MAb in ELISA. Elution at acid $\mathrm{pH}$ with glycine, which was used in this study, did not alter the antigenicity of either the S1, N or M in comparison to elution at neutral $\mathrm{pH}$ with ammonium isothiocynate which was used in studies performed by others $[11,26]$. The $\mathrm{N}$ and $\mathrm{M}$ antigens were the most and the least immunogenic, inducing ELISA antibodies after two and four immunizations, respectively. At least three immunizations with the S1 glycoprotein were necessary to induce ELISA antibodies however $\mathrm{VN}$ antibodies were not present at that time. In studies of Hasony and Macnaughton [16] with $\mathrm{MHV}$, the peplomer $\mathrm{S}$ was more immunogenic than either the $\mathrm{N}$ or $\mathrm{M}$ proteins, whereas in studies of Mockett [26] the M protein of IBV, purified using ammonium isothiocyanate, was more immunogenic in rabbits than the peplomer S.

The S1 glycoprotein obtained by immunoaffinity purification was less effective in inducing VN and $\mathrm{HI}$ antibodies than the S1 glycoprotein present in inactivated virus although a greater amount was used for immunization than that present in inactivated $\mathrm{N} 1 / 62$ virus. Three immunizations with the inactivated $\mathrm{N} 1 / 62$ induced $\mathrm{VN}$ and $\mathrm{HI}$ antibodies in $60 \%$ of chickens whereas only $10 \%$ of chickens immunized three times with the purified S1 glycoprotein had VN antibodies. Possibly the purification in the presence of detergents has affected the immunogenicity of the S1. Another more likely reason for the poor immunogenicity of the purified S1 might be the lack of association with the S2 glycoprotein, a conformation which enables a correct presentation 'of antigenic sites in the $\mathrm{S} 1$ glycoprotein to the immune system and which is present in inactivated virus $[8,9]$. The purified peplomer $\mathrm{S}$ of MHV, containing both the S1 and S2 glycoproteins, induced a considerable level of VN antibodies in all mice following two immunizations [11]. Only the S1 glycoprotein of the peplomer $\mathrm{S}$ was obtained using MAb 5-immunoadsorbent and this was the case regardless whether elution was carried out at acid or neutral $\mathrm{pH}$. Contrary 
to that, the peplomer S of IBV and MHV containing the S1 and S2 glycoproteins, were obtained using elution at neutral $\mathrm{pH}$ with ammonium isothiocyanate $[11,26]$. The reason for this discrepancy is not clear.

Immunization of chickens with inactivated N1/62 virus and purified S1 antigen was less effective than immunization with live virus in spite of using a considerably larger amount of antigen for immunization. Inactivated IBV vaccines are poor inducers of protection if administered to unprimed chickens and live attenuated IBV have been used for control of IBV-infections [19]. The protective antigen of IBV must therefore be delivered via a replicating agent if currently used live vaccines are to be replaced by subunit vaccines.

In this study protection induced by the purified S1 glycoprotein and inactivated IBV did not correlate with the presence of circulating antibodies. Chickens were protected in the absence of VN and $\mathrm{HI}$ antibodies and conversely some chickens with circulating VN, HI and ELISA antibodies were not protected. Only in one third of chickens did the presence of VN antibodies correlate with protection. The mechanism of protection in coronavirus infection is not clear. Antibodies were implicated in protection in a number of coronavirus induced diseases. Suckling mice and piglets have been protected from development of acute disease if nursed by immunized dams $[13,17,28]$ and antibody levels correlated with protection in mice immunized with the peplomer $\mathrm{S}$ [11, $16,32]$. Abrogation of $B$ cells in chickens leads to more severe and longer lasting infection [10] suggestive of the role of antibodies in protection. In other studies, however, antibodies such as VN antibodies, did not correlate with protection $[9,21]$. Cell mediated immunity is generally believed to be of importance in protection against coronavirus infections. Adoptive transfer of $\mathrm{CD}^{+}$and $\mathrm{CD}^{+}$cells and virus specific T-cells prevented development of acute disease in mice $[31,37]$. The $N$ antigen of IBV, as well as the $S$ and $M$ antigens of murine hepatitis virus, were shown to carry $\mathrm{T}$-cell epitopes $[2,25]$ suggestive of the involvement of cell mediated immunity in coronavirus infections.

There was an indication that the protection of tracheal and kidney tissues in IBV-infection, may differ. Intramuscular immunization with the S1 glycoprotein, and inactivated N1/62 to a lasser degree, provided better protection for kidneys than tracheas. Whether this difference in protection resulted from the route of antigen delivery or reflects separate pathways by which trachea and kidney tissue become infected, remains to be determined. Differential protection of target tissues has also been observed in some instances with MHV [1].

\section{Acknowledgements}

The authors thank Fiona Ashton for excellent assistance. Special thanks are due to Ms. Sue Federizzi and Ms. Carmel Rogan for their care of chickens used in this study. This work was supported in part by the Australian Chicken Meat and Egg Industry Research and Development Councils. 


\section{References}

1. Barthold SW, Smith AL (1989) Virus strain specificity of challenge immunity to coronavirus. Arch Virol 104: 187-196

2. Boots AMH, Kusters JG, Van Noort JM, Zwaagstra KA, Rijke E, Van Der Zeijst BAM, Hensen EJ (1991) Localization of a T-cell epitope within the nucleocapsid protein of avian coronavirus. Immunology 74: 8-13

3. Boots AMH, Benaissa-Trouw BJ, Hesselink W, Rijke E, Schrier C, Hensen EJ (1992) Induction of anti-viral immune responses by immunization with recombinant-DNA encoded avian coronavirus nucleocapsid protein. Vaccine 10: 119-124

4. Boursnell MEG, Binns MM, Foulds IJ, Brown TDK (1985) Sequences of the nucleocapsid genes from two strains of avian infectious bronchitis virus. J Gen Virol 66: $573-580$

5. Cavanagh D (1983) Coronavirus IBV glycopolypeptides: size of their polypeptide moieties and nature of their oligosaccharides. J Gen Virol 64: 1187-1191

6. Cavanagh D (1983) Coronavirus IBV: further evidence that the surface projections are associated with two glycopolypeptides. J Gen Virol 64: 1787-1791

7. Cavanagh D (1983) Coronavirus IBV: structural characterization of the spike protein. J Gen Virol 64: 2577-2583

8. Cavanagh D, Darbyshire JH, Davis P, Peters RW (1984) Induction of humoral neutralising and haemagglutination-inhibiting antibody by the spike protein of avian infectious bronchitis virus. Avian Pathol 13: 573-583

9. Cavanagh D, Davis PJ, Darbyshire JH, Peters RW (1986) Coronavirus IBV: virus retaining spike glycopolypeptide $\mathrm{S} 2$ but not $\mathrm{S} 1$ is unable to induce virus-neutralizing or haemagglutination-inhibiting antibody, or induce chicken tracheal protection. J Gen Virol 67: 1435-1442

10. Cook JKA, Davison TF, Huggins MB, Mclaughlan P (1991) Effect of in ovo bursectomy on the course of an infectious bronchitis virus infection in line $\mathrm{C}$ White Leghorn chickens. Arch Virol 118: 225-234

11. Daniel C, Talbot PJ (1990) Protection from lethal coronavirus infection by affinitypurified spike glycoprotein of murine hepatitis virus, strain A59. Virology 174: 87-94

12. Darbyshire JH, Rowell JG, Cook JKA Peters RW (1979) Taxonomic studies on strains of avian infectious bronchitis virus using neutralisation tests in tracheal organ cultures. Arch Virol 61: 227-238

13. De Diego M, Laviada MD, Ehjuanes L, Escribano JM (1992) Epitope specificity of protective lactogenic immunity against swine transmissible gastroenteritis virus. J Virol 66: 6502-6508

14. De Groot RJ, Van Leen RW, Dalderup MJM, Vennema H, Horzinek MC, Spann WJM (1989) Stably expressed FIPV peplomer protein induces cell fusion and elicits neutralizing antibodies in mice. Virology 171: 493-502

15. Fleming JO, Shubin RA, Sussman MA, Casteel N, Stohlman SA (1989) Monoclonal antibodies to the matrix (E1) glycoprotein of mouse hepatitis virus protect mice from encephalitis. Virology 168: 162-167

16. Hasony HJ, Macnaughton MR (1981) Antigenicity of mouse hepatitis virus strain 3 subcomponents in C57 strain mice. Arch Virol 69: 33-41

17. Homberger FR, Barthold SW (1992) Passively aquired challenge immunity to enterotropic coronavirus in mice. Arch Virol 126: 35-43

18. Ignjatovic J, Mcwaters PG (1991) Monoclonal antibodies to three structural proteins of avian infectious bronchitis virus: characterization of epitopes and antigenic differentiation of Australian strains. J Gen Virol 72: 2915-2922

19. King DJ, Cavanagh D (1991) Infectious bronchitis. In: Calnek BW, Barnes HJ, Beard 
CW, Reid WM, Yoder HW Jr (eds) Diseases of poultry, 9th edn. Iowa State University Press, Ames, pp 471-484

20. Koch G, Hartog L, Kant A, Van Roozelaar DJ (1990) Antigenic domains on the peplomer protein of avian infectious bronchitis virus: correlation with biological functions. J Gen Virol 71: 1929-1935

21. Koolen MJM, Borst MAJ, Horzinek MC, Spaan WJM (1990) Immunogenic peptide comprising a mouse hepatitis virus A59 B-cell epitope and an influenza virus T-cell epitope protects against lethal infection. J Virol 64: 6270-6273

22. Kusters JG, Jager EJ, Niesters HGM, Van Der Zeijst BAM (1990) Sequence evidence of RNA recombination in field isolates of avian coronavirus infectious bronchitis virus. Vaccine 8: 605-608

23. Kusters JG, Jager EJ, Lenstra JA, Koch G, Posthumus WPA, Meloen RH, Van Der Zeijst BAM (1989) Analysis of an immunodominant region of infectious bronchitis virus. J Immunol 143: 2692-2698

24. Lenstra JA, Kusters JG, Koch G, Van Der Zeijst BAM (1989) Antigenicity of the peplomer protein of infectious bronchitis virus. Mol Immunol 26: 7-15

25. Mobley J, Evans G, Dailey MO, Perlman S (1992) Immune response to a murine coronavirus: identification of a homing receptor-negative $\mathrm{CD} 4^{+} \mathrm{T}$ cell subset that responds to viral glycoproteins. Virology 187: 443-452

26. Mockett APA (1985) Envelope proteins of avian infectious bronchitis virus: purification and biological properties. J Virol Methods 12: 271-278

27. Mockett APA, Cavanagh D, Brown TDK (1984) Monoclonal antibodies to the S1 spike and membrane proteins of avian infectious bronchitis coronavirus strain Massachusetts M41. J Gen Virol 65: 2281-2286

28. Perlman S, Schelper R, Ries D (1987) Maternal antibody-modulated MHV-JHM infection in C57BL/6 and Balb/c mice. Adv Exp Med Biol 218: 297-305

29. Spaan WJM (1990) Progress towards a coronavirus recombinant DNA vaccine. In: Cavanagh D, Brown TDK (Eds) Coronaviruses and their diseases. Plenum Press, New York, pp 201-203

30. Sturman LS, Ricard CS, Holmes KV (1985) Proteolytic cleavage of the E2 glycoprotein of murine coronavirus: activation of cell-fusing activity of virions by trypsin and separation of two different $90 \mathrm{~K}$ cleavage fragments. J Virol 56: 904-911

31. Sussman MA, Shubin RA, Kyuwa S, Stohlman SA (1989) T-cell-mediated clearance of mouse hepatitis virus strain JHM from the central nervous system. J Virol 63: 3051-3056

32. Talbot PJ, Dionne G, Lacroix M (1988) Vaccination against lethal coronavirus-induced encephalitis with a synthetic decapeptide homologous to a domain in the predicted peplomer stalk. J Virol 62: 3032-3036

33. Vennema H, De Groot RJ, Harbour DA, Dalderup M, Gruffydd-Jones T, Horzinek MC, Spaan WJM (1990) Early death after feline infectious peritonitis virus challenge due to recombinant vaccinia virus immunization. J Virol 64: 1407-1409

34. Vennema H, De Groot RJ, Harbour DA, Horzinek MC, Spaan WJM (1991) Primary structure of the membrane and nucleocapsid protein genes of feline infectious peritonitis virus and immunogenicity of recombinant vaccinia viruses in kittens. Virology 181: $327-335$

35. Wang L, Junker D, Collisson EW (1993) Evidence of natural recombination within the $\mathrm{S} 1$ gene of infectious bronchitis virus. Virology 192: 710-716

36. Wesseling JG, Godeke G-J, Schijns VECJ, Prevec L, Graham FL, Horzinek MC, Rottier PJM (1993) Mouse hepatitis virus spike and nucleocapsid proteins expressed by adenovirus vectors protect mice against a lethal infection. J Gen Virol 74: 2061-2069 
37. Yamaguchi K, Goti N, Kyuwa S, Hayami M, Toyoda Y (1991) Protection of mice from a lethal coronavirus infection in the central nervous system by adoptive transfer of virus-specific $T$ cell clones. J Neuroimmunol 32: 1-9

Authors' address: Dr. J. Ignjatovic, CSIRO Division of Animal Health, Animal Health Research Laboratory, Private Bag No. 1, Parkville, Victoria 3052, Australia.

Received January 6, 1994 